\title{
Consumption of aquatic macrophytes by the Red-gartered Coot Fulica armillata (Birds: Rallidae) in a coastal wetland of north central Chile
}

\section{Consumo de macrófitas acuáticas por la Tagua común Fulica armillata (Aves: Rallidae) en un humedal costero del centro norte de Chile}

\author{
Carlos Velásquez ${ }^{1,2 *}$, Eduardo Jaramillo ${ }^{3}$, Patricio A. Camus ${ }^{4} \&$ Cristina San Martín ${ }^{3}$ \\ ${ }^{1}$ Programa de Magíster en Ciencias mención Recursos Hídricos, Escuela de Graduados, Facultad de Ciencias, Universidad \\ Austral de Chile, Casilla 567, Valdivia, Chile. \\ ${ }^{2}$ Instituto de Fomento Pesquero, Dr. Marín 340, Coquimbo, Chile. \\ ${ }^{3}$ Instituto de Ciencias de la Tierra, Facultad de Ciencias, Universidad Austral de Chile, Casilla 567, Valdivia, Chile. \\ ${ }^{4}$ Departamento de Ecología, Facultad de Ciencias y Centro de Investigación en Biodiversidad y Ambientes Sustentables \\ CIBAS, Universidad Católica de la Santísima Concepción, CP 4090541, Concepción, Chile. \\ *cfvelasque@gmail.com
}

\begin{abstract}
The Red-gartered Coot Fulica armillata, is a common herbivorous water bird in coastal wetlands of the southern Neotropical region. Microhistological analyses of feces collected at the coastal wetland of Punta Teatinos (north central Chile; 29 ${ }^{\circ} \mathrm{S}$ ), show that this coot feeds predominantly on Stuckenia pectinata, the most abundant submerged macrophyte at this area. The foraging behavior of $F$. armillata is discussed in regard with its ecological role as a primary consumer on coastal wetlands.

RESUMEN

La Tagua común Fulica armillata, es un ave acuática herbívora común en los humedales costeros del extremo sur de la región del Neotrópico. Análisis microhistológicos de fecas recolectadas en el humedal de Punta Teatinos (centro norte de Chile; $29^{\circ} \mathrm{S}$ ) indican que esta tagua consume primariamente a Stuckenia pectinata, la macrófita sumergida más abundante en esta área. Se discute el comportamiento de forrajeo de $F$. armillata con respecto a su rol ecológico como consumidor primario en humedales costeros.
\end{abstract}

The Red-gartered Coot Fulica armillata (Vieillot, 1817) (Aves: Rallidae) is one of the six species of this genus occurring in limnetic wetlands of the southern Neotropical region, including Chile, Argentina, Uruguay and southeastern Brazil (Couve et al. 2016). In Chile, this coot has a wide latitudinal distribution: from the Río Copiapó in the north $\left(\sim 27^{\circ} \mathrm{S}\right)$ to Isla Grande de Tierra del Fuego and Isla Navarino in the south $\left(\sim 54^{\circ} \mathrm{S}\right)$ (Medrano et al. 2018). This species has been described as a primarily herbivorous waterbird, although its diet also includes invertebrates although in lower proportion than plants (Ruíz 1993; García et al. 2008).

The abundance of $F$. armillata in the southern Neotropical region has been estimated in $\sim 1,000,000$ birds (Waterbird Population Estimates 2017). Thus, and due to its herbivorous feeding habits, this bird may potentially play an important role both as controller of the biomass of aquatic macrophytes and as seed disperser (Ruíz 1993; Bortolus et al. 1998; Charalambidou \& Santamaría 2005), as shown for other coots such as Fulica cristata (Gmelin, 1789) (Stewart \& Bally 1985), Fulica atra (Linnaeus, 1758) (Perrow et al. 1997) and Fulica americana (Gmelin, 1789) (Esler 1989). Despite the important ecological role of coots, the natural history of $F$. armillata in Chile is scarcely known. Cody (1970) and Riveros et al. (1981) studied the spatial distribution of this bird in wetlands of central Chile (c. $30-38^{\circ} \mathrm{S}$ ), Silva et al. (2011) described its reproductive biology in Laguna Santa Elena (central Chile; $36^{\circ} \mathrm{S}$ ), while Kennedy (1977) and Ruíz (1993) studied ecological and trophic aspects at the wetland of Río Cruces (southern Chile; $29^{\circ} \mathrm{S}$ ). However, no studies have been carried out on populations of $F$. armillata along the semiarid coastal region of northern Chile, where coastal wetlands host a different suite of waterbirds compared to their southern counterparts (Sielfeld et al. 2012). An important wetland at that region is Punta Teatinos (PT hereafter), located north of the conurbation of Coquimbo and La Serena in north central Chile ( $29^{\circ}$ S; Fig. 1a, b), where field observations carried 
out during 2016-17 showed that $F$. armillata is one of the most abundant resident herbivorous waterbirds. Therefore, this study was aimed to provide a first assessment of the use of plant food resources by $F$. armillata at the PT wetland, based on a microhistological analysis of its feces and a comparison with published results.

The PT wetland is a coastal lagoon of $\sim 69$ ha with freshwater inflows from the ravine El Romeral and salty water influence from the nearby sand beach surf zone during extreme high tides (Jorge et al. 1998). Stuckenia pectinata (L.) Börner is the most abundant submerged macrophyte at this lagoon (C. Velásquez, obs. Pers.). The western side of the wetland (see Fig. 1c) is bordered by the upper shore sandy beach level, which $F$. armillata used as dropping area. Thus, during May 2016, fresh feces of the Red-gartered Coot $(n=30)$ were randomly collected along the western sandy bank of PT, and then stored in sealed plastic bags with alcohol $(70 \%)$ to preserve them. Additionally, with the aim of maximizing the likelihood that collected feces belonged to different coot individuals, the sampling was carried out through the entire border of the lagoon, at places used by red-gartered coots as resting or passing spots.

In order to identify the species of plants in the feces, a series of microhistological techniques (after Johnson et al. 1983) to analyze food habits of herbivores were used to (i) prepare samples of epidermal cells collected from the macrophytes of the PT wetland, (ii) compare those samples with the plant epidermal cells found intact in coot feces, and (iii) quantify the examined material. The comparisons were carried out with an optic microscope (10x magnification) connected to the software Micrometrics Premium to obtain high resolution digital pictures (ACCU-SCOPE camera) (see Velásquez et al. 2018).

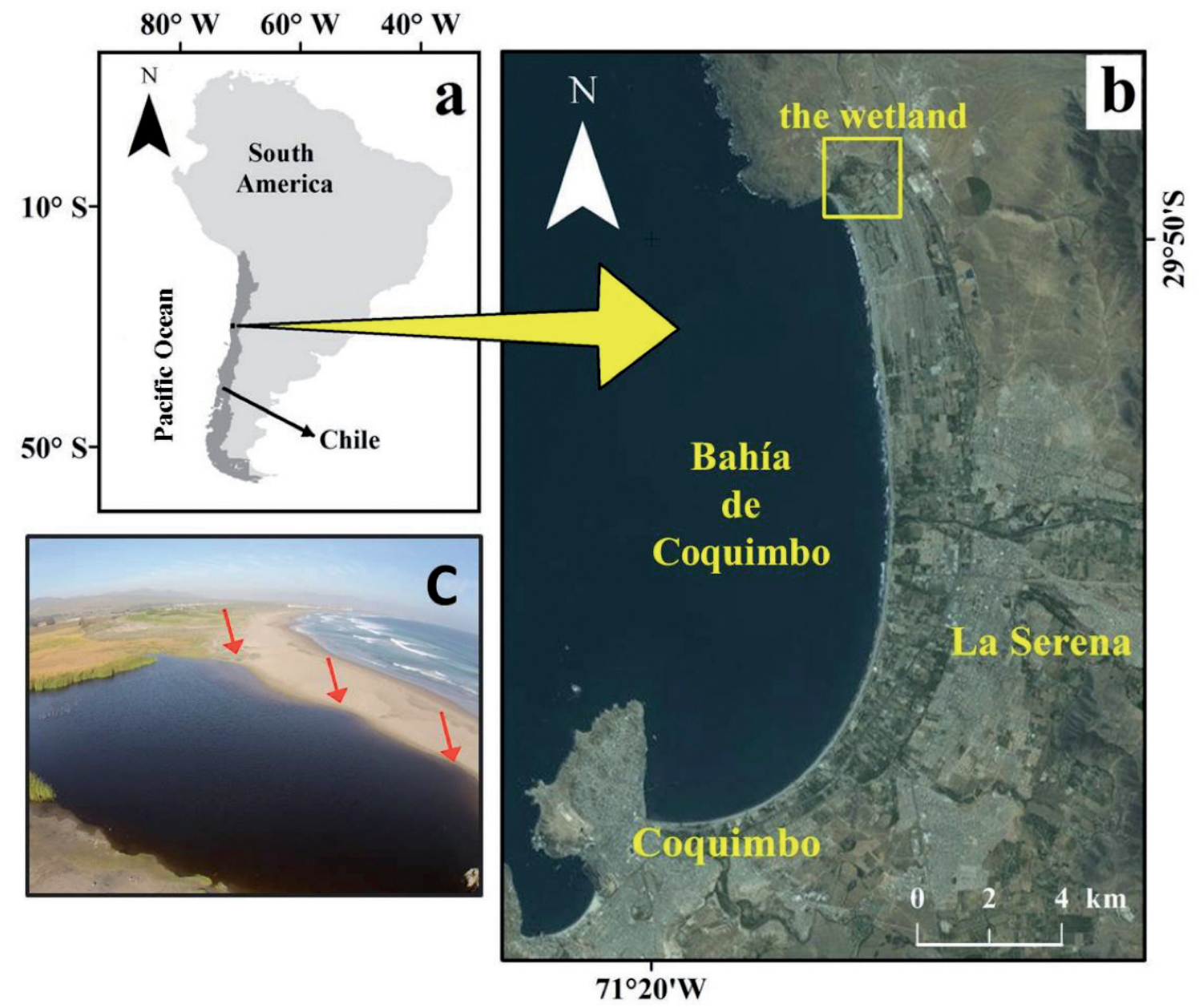

FIgURE 1. Geographic location of the wetland of Punta Teatinos, in north central Chile (a) and at the northern side of Bahía de Coquimbo (b). A general picture of the wetland is also included (c); the red arrows indicate the western side of the wetland where the feces of coots were collected. / Localización geográfica del humedal de Punta Teatinos, en el centro norte de Chile (a) y en el costado norte de Bahía de Coquimbo (b). Se incluye una foto general del área de estudio (c); las flechas rojas indican el lado oeste del humedal donde se recolectaron las fecas de las taguas. 
The results were first expressed as the percent occurrence frequency of each plant species in the sample of 30 feces (replicates). However, this measure cannot clearly reflect the intensity of consumption of food items, considering that the presence of different plants in each feces is recorded only once, regardless of the amount of biomass ingested of each plant. Therefore, an exhaustive subsampling was conducted in order to obtain an estimate of the incidence of each plant species within the feces. To that purpose, two portions from each feces (herein referred to as subsamples) were randomly selected, and each subsample was uniformly spread out in a Neubauer counting chamber, where 10 optic fields of 1 $\mathrm{mm}^{2}$ were also randomly selected for observation, thus examining a total of 600 fields (i.e. 10 fields $\mathrm{x} 2$ chambers $\mathrm{x}$ 30 feces). The presence of each plant species in each set of 10 fields per chamber was recorded as a percent frequency, and the two frequency values recorded for each feces were then averaged. Finally, the incidence of each plant species was expressed as the grand average ( $\pm \mathrm{SE}$ ) of the 30 average values obtained from the feces collected in the PT wetland.

The analysis of feces showed that the only conspicuous macrophytes consumed by $F$. armillata were Cotula coronopifolia L., Sarcocornia fruticosa (L.) Scott, and $S$. pectinata which was by far the dominant food item (Fig. 2). Remarkably, S. pectinata was present not only at all feces, with an occurrence frequency of $100.0 \%$, but also at each of the 600 optic fields examined, with an incidence of $100.0 \pm 0.0 \%$ (Table 1 ) suggesting a heavy consumption by this species. In contrast, the occurrence frequency of C. coronopifolia and S. fruticosa in the 30 feces was 66.7 $\%$ and $36.7 \%$, respectively, but their incidence within the feces was much lower, reaching only $13.9 \pm 0.6 \%$ and 15.3 $\pm 1.0 \%$, respectively (Table 1 ). In addition, these results were consistent with the different life habits of the three macrophytes (see Ramírez \& San Martín 2006), indicating that coots fed predominantly on submerged (S. pectinata) rather than marshland (C. coronopifolia and S. fruticosa) plants (Table 1).

Albeit the above results do not allow a proper evaluation of feeding preferences (e.g. Jacksic et al. 1979), prior antecedents suggest that the high dietary importance of $S$. pectinata would not be due to its selective consumption by coots, but rather to its submerged habit and its high abundance at the PT wetland. Unlike other Chilean coots such as Fulica leucoptera (Vieillot, 1817) and Fulica rufifrons (Philippi \& Landbeck, 1861), F. armillata is known to display its foraging activities mainly at the central, deeper portion of lagoons (Cody 1970; Riveros et al. 1981). On the other hand, in shallower, non-lagoon wetlands such as the large wetland of Río Cruces (southern Chile), both $F$. armillata and F. leucoptera (see Table 1 ) feed primarily ( $\sim 85 \%$ ) on the submerged and most abundant macrophytes (particularly Egeria densa Planch; Ramírez et al. 1991; Ruíz 1993), a pattern shown also by other common water birds such as the Black-necked Swan Cygnus melancoryphus (Molina, 1782) (Table 1; Corti \& Schlatter 2002; Norambuena \& Bozinovic 2009). Thus, F. armillata would behave as an opportunistic consumer, although future studies should clarify whether the submerged habit itself is a factor influencing the feeding choice of this species.

On a general level, the similar foraging patterns of the commonest herbivorous birds across wetlands of Chile and the southern Neotropical region (Couve et al. 2016) might play an important role in the succession of macrophyte assemblages. Submerged macrophytes such as S. pectinata, E. densa and Ruppia maritima L. are dominant in coastal wetlands of the southern Neotropic, and the large amount of plant necromass derived from bird foraging may determine the zonation and successional patterns of the vegetation, or even retard the successional process (Ruíz 1993; Bortolus et al. 1998; Corti \& Schlatter 2002).
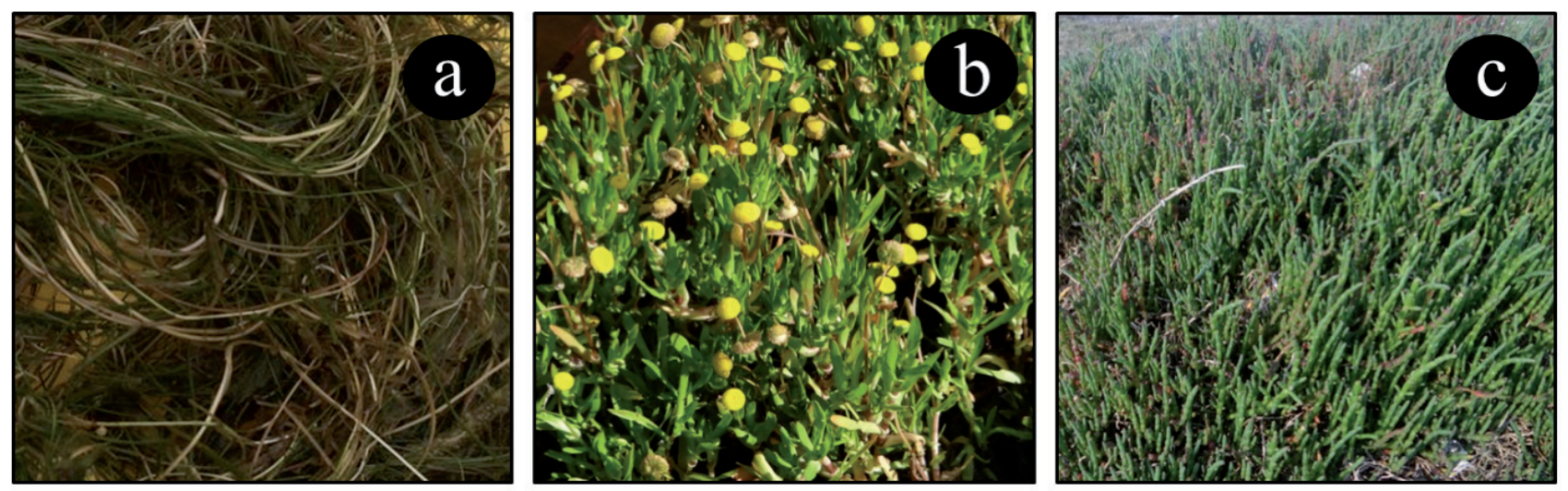

FiguRE 2. Pictures of the aquatic macrophytes consumed by Fulica armillata in the study area: Stuckenia pectinata (a), Cotula coronopifolia (b) and Sarcocornia fruticosa (c). / Fotografías de las macrófitas acuáticas consumidas por Fulica armillata en el área de estudio: Stuckenia pectinata (a), Cotula coronopifolia (b) and Sarcocornia fruticosa (c). 
TABLE 1. Frequency of occurrence of the food items of herbivorous waterbirds in coastal wetlands of Chile (Fulica armillata, Fulica leucoptera and Cygnus melancoryphus). The macrophytes are classified by their life habits (see Ramírez \& San Martín 2006). Food items were determined throughout analyses of feces $(*)$ and analyses of stomach contents $(* *)$. / Frecuencia de ocurrencia del ítem alimentario de aves acuáticas herbívoras en humedales costeros de Chile (Fulica armillata, Fulica leucoptera y Cygnus melancoryphus). Las macrófitas se clasifican según sus hábitos de vida (ver Ramírez \& San Martín 2006). Los ítems alimentarios fueron determinados a través del análisis de fecas $(*)$ y análisis de contenido estomacal $(* *)$.

\begin{tabular}{|c|c|c|c|c|c|c|}
\hline \multirow{4}{*}{ FoOD ITEMS (\%) } & \multirow{3}{*}{$\begin{array}{l}\text { THIS STUDY* } \\
\text { F. armillata } \\
\text { P. Teatinos }\end{array}$} & \multicolumn{2}{|c|}{ Ruíz (1993)** } & \multicolumn{2}{|c|}{ Corti \& Schlatter } & $\begin{array}{c}\begin{array}{c}\text { Norambuena \& } \\
\text { Bozinovic }\end{array} \\
(2009)^{*}\end{array}$ \\
\hline & & F. armillata & F. leucoptera & \multicolumn{2}{|c|}{ C. melancoryphus } & C. melancoryphus \\
\hline & & Río Cruces & Río Cruces & Río Cruces & Chihuao & Lago Budi \\
\hline & $\mathrm{n}=30$ & $\mathrm{n}=18$ & $\mathrm{n}=7$ & $\mathrm{n}=13$ & $\mathrm{n}=8$ & $\mathrm{n}=10$ \\
\hline
\end{tabular}

Submerged

Stuckenia pectinata

Stuckenia striata

Potamogeton pusillus

Egeria densa

Free floating

Limnobium laevigatum

Floating

Ludwigia peploides

Hydrocotyle ranunculoides

Marshland

Puccinellia glaucescens

Cotula coronopifolia

Sarcocornia fruticosa
100.0

78.0

$\begin{array}{cccc}2.2 & 1.0 & 7.6 & 1.3 \\ 85.3 & 84.8 & 91.9 & 71.7\end{array}$

$<1.0$

24.7

$<1.0$

2.1
Thus, the close connection between submerged macrophytes and herbivorous waterbirds such as $F$. armillata would make wetlands highly sensitive to bottomup forcing. For instance, industrial activities triggered sudden environmental changes at the Río Cruces wetland in 2004, leading to a radical decline in the spatial cover of $E$. densa and the population abundance of F. armillata and others birds (e.g. Jaramillo et al. 2007; Lagos et al. 2008). Only eight years later, macrophytes begun to recover and a concomitant increase in the abundance of coots was observed (Jaramillo et al. 2018a, 2018b), although the mechanisms underlying their decline and subsequent recovery remain not fully understood.

Even though $F$. armillata is not considered an endangered species (Bird Life International 2017), a better knowledge of its trophic ecology may provide crucial information for the management and restoration of coastal wetlands over the southern Neotropical region.

\section{ACKNOWLEDGEMENTS}

We thank to Felipe Dreves (http://www.lluviafilms.com), Wolfgang Stotz (Universidad Católica del Norte, Chile) and Emilio Acuña (Ecosistema Ltda.) for logistical support. CV thanks the support of Escuela de Graduados, Facultad de Ciencias (UACh), Vicerrectoría de Investigación \& Creación Artística (Proyecto: I-2015-10; UACh) and Beca de Asistencia Académica de la Dirección de Postgrado (2015-2016; UACh). 


\section{REFERENCES}

Waterbird Population Estimates. 2017. Species factsheet: Fulica armillata. URL: http://www.wpe.wetlands.org. Accessed: December 5, 2018.

BirdLife InTERnATIONAL. 2017. Species factsheet: Fulica armillata. URL: http://www.birdlife.org. Accessed: October 15, 2017.

Bortolus, A., Iribarne, O.O., MartíneZ, M.M. 1998. Relationship between waterfowl and the seagrass Ruppia maritima in a southwestern Atlantic coastal lagoon. Estuaries 21: 170717.

Charalambidou, I., Santamaría, L. 2005. Field evidence for the potential of waterbirds as dispersers of aquatic organisms. Wetlands 25(2): 252-258.

Cody, M. 1970. Chilean bird distribution. Ecology 59:455-464.

Corti, P., Schlatter, R. 2002. Feeding ecology of Black-necked swan Cygnus melancoryphus in two wetlands of Southern Chile. Studies on Neotropical Fauna and Environment 37: 9-14.

Couve, E., Vidal, C.F., Ruíz, J. 2016. Aves de Chile, sus Islas Oceánicas y Península Antártica. FS Editorial, Punta Arenas. $551 \mathrm{pp}$.

EsLER, D. 1989. An assessment of American coot herbivory of Hydrilla. Journal of Wildlife Management 53: 1147-1149.

García, G.O., Favero, M., Mariano-Jelicich, R. 2008. Redgartered Coot Fulica armillata feeding on the grapsid crab Cyrtograpsus angulatus: advantages and disadvantages of an unusual food resource. Ibis 150: 110-114.

JAKSIC, J.M. 1979. Técnicas estadísticas simples para evaluar selectividad dietaria en Strigiformes. Medio Ambiente 4: 114-118.

Jaramillo, E., Schlatter, R., Contreras, H., Duarte, C., Lagos, N., Paredes, E., Ulloa, J., Valenzuela, G., Peruzzo, B., SiLvA, R. 2007. Emigration and mortality of black-necked swans (Cygnus melancoryphus) and disappearance of the macrophyte Egeria densa in a Ramsar wetland site of southern Chile. Ambio 36: 607-610.

Jaramillo, E., Lagos, N.A., Labra, F.A., Paredes, E., Acuña, E.O., Melnick, D., Manzano, M., Velásquez, C., Duarte, C. 2018a. Recovery of Black-necked Swans, macrophytes and water quality in a Ramsar wetland of southern Chile: assessing resilience following sudden anthropogenic disturbances. Science of the Total Environment 628: 291301.

Jaramillo, E., Duarte, C., Labra, F.A., Lagos, N.A., Peruzzo, B., Velásquez, C., Manzano, M., Melnick, D., Silva, R. 2018b. Resilience of an aquatic macrophyte to an anthropogenically induced environmental stressor in a Ramsar wetland of southern Chile. AMBIO DOI: 10.1007/ s13280-018-1071-6.

Johnson, M.K., Wofford, H., Pearson, H.A. 1983. Microhistological techniques for food habits analyses. Forest Service, New Orleans. 40 pp.

Jorge, R., Tabilo-Valdivieso, E., Moncada, V. 1998. Avifauna de la Laguna de Punta Teatinos y ecosistemas adyacentes, Bahía de Coquimbo, Chile. Boletín Chileno de Ornitología 5: 2-9.
Kennedy, M.E. 1977. Requisitos para el hábitat de reproducción de la tagua común (Fulica armillata) y recomendaciones técnicas de manejo para aumentar esta especie. Medio Ambiente 2: 107-116.

Lagos, N.A., Paolini, P., Jaramillo, E., Lovengreen, C., Duarte, C., Contreras, H. 2008. Environmental processes, water quality degradation, and decline of waterbird populations in the Río Cruces wetland, Chile. Wetlands 28: 938-950.

Medrano, F., Barros, R., Norambuena, H.V., Matus, R., Schmitt, F. 2018. Atlas de las aves nidificantes de Chile. Red de Observadores de Aves y Vida Silvestre de Chile, Santiago. $658 \mathrm{pp}$.

Norambuena, C.M., Bozinovic, F. 2009. Health and nutritional status of a perturbed Black-necked swan (Cygnus melancoryphus) population: diet quality. Journal of Zoo and Wildlife Medicine 40: 607-616.

Perrow, M.R., Schutten, J.H., Howes, J.R., Holzer, T., Madgwick, F.J., JowitT, A.J. 1997. Interactions between coot (Fulica atra) and submerged macrophytes: the role of birds in the restoration process. Hydrobiologia 342/343: 241-255.

Ramírez, C., San Martín, C., Medina, R., Contreras, D. 1991. Estudio de la flora hidrófila del Santuario de la Naturaleza "Río Cruces" (Valdivia, Chile). Gayana Botanica 48: 6780.

Ramírez, C., San Martín, C. 2006. Diversidad de macrófitos chilenos. En: Vila, I., Veloso, A., Schlatter, R., Ramírez, C. (Eds.). Macrófitas y vertebrados de los sistemas límnicos de Chile. Editorial Universitaria, Santiago, Chile. pp. 2160.

Riveros G., Serey, I., Drouilly, P. 1981. Estructura y diversidad de la comunidad de aves acuáticas de la laguna El Peral, Chile Central. Anales del Museo de Historia Natural 14: 189-196.

Ruíz, J. 1993. Estudio ecológico en tres especies de taguas residentes en el Santuario de la Naturaleza del río Cruces. Tesis. Universidad Austral de Chile, Valdivia, Chile.

Silva, C., Barrientos, C., Figueroa, R.A., Martín, N., Contreras, A., Ardiles, K., Moreno, L., GonzÁlez-Acuña, D. 2011. Biología reproductiva de la tagua común (Fulica armillata) y la tagua de frente roja (Fulica rufifrons) en un área agroforestal del centro-sur de Chile. Gayana 75: 161-169.

Sielfeld, W., Fuentes, R., Peredo, R., Malinarich, V., Olivares, F. 2012. Humedales costeros del norte de Chile. En: Humedales costeros de Chile. Aportes científicos a su gestión sustentable (Eds. Fariña J.M., Camaño, A.), pp. 147-213. Ediciones Universidad Católica de Chile, Santiago.

Stewart, B.A., Bally, R. 1985. The ecological role of the Redknobbed Coot Fulica cristata Gmelin at the Bot River Estuary South Africa: a preliminary investigation. Transactions of the Royal Society of South Africa 45: 419-426.

Velásquez, C., San Martín, C., Jaramillo, E., Camus P.A. 2018. Catálogo microhistológico de macrófitas acuáticas de dos humedales costeros de Chile: Una herramienta para estudios tróficos en aves acuáticas herbívoras. Revista Chilena de Ornitología 24: 79-84. 